\title{
MENGUAK KONSEP KEBERSANDINGAN FETHULLAH GULEN DAN ASIMILASI BUDAYA TARIQ RAMADHAN
}

\author{
Ika Yunia Fauzia*
}

\begin{abstract}
A bstract: the wave of immigration of Muslims to European countries has brought with it the serious consequences as to how these Muslims should adapt culturally and religiously to the entirely different circumstances. Some Muslim intellectuals - like Fethullah Gulensuggested that Muslims should maintain the cultural co-existence in a way that would not endanger their religious tradition while at the same time bring a state of peace both for themselves and for the communities they live in. Tariq Ramadhan in the meantime suggested that Muslims be committed to what he calls the cultural assimilation whereby they put aside their cultural upbringing from their country of origin and assimilate fully into the cultural live of Europe. Hence, this paper is about the analysis of the cultural dilemma that M uslims face in Europe by referring to the thought of Gulen and Ramadhan on the issue at hand. Although the context of the paper is limited to Europe, the content of the analysis is presented in such a way that it may also be relevant to similar problems faced by Muslims in different cultural and social settings.
\end{abstract}

Keywords: cultural co-existence, cultural assimilation

\section{Pendahuluan}

Keberadaan kaum Muslim di Eropa seringkali mendatangkan problematika budaya tersendiri. Orang Muslim yang datang ke Eropa dari berbagai penjuru dunia Islam membawa budaya dan kebiasan lokal mereka ke tempat baru yang memiliki budaya dan kebiasaan yang sama sekali berbeda. Muncul pertanyaan, apakah para pendatang ini harus mempertahankan budaya dan kebiasaan mereka tapi berhadapan dengan masalah dengan budaya setempat, atau mereka harus mengorbankan budaya mereka dan berasimilasi dengan budaya baru? atau adakah strategi lain yang harus mereka lakukan?

Inilah yang coba dilakukan Fethullah Gulen dan Tariq Ramadhan. Mereka berdua berusaha menjawab pertanyaan-pertanyaan semacam itu yang selama ini menjadi sumber keresahan dan pemikiran bagi generasi M uslim yang hidup di Eropa. Pandangan G ulen dan Ramadhan tentang kebersandingan dan asimilasi budaya akan menjadi pembahasan tulisan ini.

Kedua tokoh ini sama-sama resah dengan masalah kebersandingan dan asimilasi budaya di Eropa. Dengan latar belakang budaya dan intelektual yang berbeda, mereka tentu memiliki jawaban dan pendekatan yang berbeda atas permasalahan ini. Namun keduanya sama-sama optimis bahwa masalah perbedaan budaya ini dapat diselesaikan dengan baik dan bijaksana.

Sementara itu, berbeda dengan kedua tokoh itu, banyak pemikir Eropa (Amerika) yang justru pessimistik bahwa berbagai budaya yang berbeda-beda dapat disandingkan secara damai. Samuel H untington adalah salah satunya. la berpendapat bahwa budaya -dan juga peradaban yang berbeda-beda- akan saling berbenturan satu sama lain tanpa adanya kemungkinan untuk

\footnotetext{
* Staf Pengajar Ma‘had U mar bin al-Kattga Surabaya
} 
terjadinya keberbersandingan apalagi asimilasi.

Teori H untington tentang benturan peradaban itu sendiri telah menimbulkan perdebatan sengit di banyak negara di kalangan para sarjana sejak dia menerbitkan artikelnya dan buku tentang topik ini pada tahun 1993 dan 1996. Dia mempertahankan pendapat bahwa sumber fundamental dari konflik di dunia baru ini terutama sekali tidak bersifat ideologisatau ekonomi. Pengelompokan-pengelompokan yang terjadi di kalangan umat manusia dan sumber konflik yang mendominasi berasal dari budaya. Peradaban-peradaban dibedakan satu dengan yang lain oleh sejarah, bahasa, budaya, tradisi dan, yang paling penting, agama. Orang-orang dari peradaban-peradaban yang berbeda mempunyai pandangan-pandangan yang berbeda tentang relasi-relasi antara Tuhan dan manusia, individu dengan kelompok, warga dengan negara, orangtua dengan anak-anak, suami dengan istri, sebagaimana halnya dengan pandanganpandangan yang berbeda tentang hak-hak dan kewajiban-kewajiban keluarga, kebebasan dan otoritas (wewenang), persamaan dan hirarki. Perbedaan-perbedaan ini yang merupakan produk yang dihasilkan selama berabad-abad adalah jauh lebih fundamental dari pada perbedaanperbedaan di kalangan ideologi-ideologi politik dan rejim-rejim politik. Selama beberapa abad, perbedaan-perbedaan di antara peradaban-peradaban telah menghasilkan konflik-konflik yang paling lama dan paling ekstrem. ${ }^{1}$

Pernyataan Huntington ini membangkitkan respons internasional yang meluas, yang menimbulkan lebih banyak sikap kritis dari pada sikap setuju. Beberapa sarjana di berbagai negara Muslim mempertanyakan motif di balik pendapat Huntington itu. Tapi mereka juga mempertanyakan sejauh mana teori itu dapat dibenarkan. Kenyataannya adalah bahwa sepanjang sejarah kemanusiaan, banyak sekali budaya-budaya yang mampu untuk bersanding dan saling melebur satu sama lain tanpa ada masalah berarti yang muncul.

Di era globalisasi ini, kontak-kontak ekonomi yang semakin meningkat antara negaranegara telah mendobrak batas-batas negara, dan peradaban-peradaban yang berbeda saling bertemu dan saling melebur satu sama lain pada saat yang sama. Dalam sejarah dunia, terdapat banyak kasus seperti ini, budaya Indonesia menyerap budaya Eropa, budaya Eropa menyerap budaya Timur (Cina, J epang, India bahkan Indonesia). Batik umpamanya terbukti telah menjadi pakaian yang seolah telah mendunia dan digemari oleh banyak orang Eropa. Demikian juga dengan makanan Thailand yang sudah sedemikian luas digemari oleh orang-orang Eropa.

\section{Teori-teori tentang Pola Kontak Budaya}

Kontak budaya telah berlangsung di seluruh periode sejarah yang diketahui. Kadangkadang, kontak budaya dipengaruhi oleh cara-cara damai, di saat lain, ia dipengaruhi oleh peperangan, invasi dan penaklukan wilayah. Motivasi dari kontak budaya ini juga beragam, merentang dari ekspansi politik dan ekonomi hingga penyebaran agama-agama atau kombinasi dari unsur-unsur ini.

${ }^{1}$ Samuel H untington, The Clash of Civilisation and the Remaking of World Order (N ew York: Simon \& Schuster, 1996), 1-3. Pandangan dan tesa Huntington tentang kontak dan konflik budaya ini juga telah ia kemukakan dalam berbagai karyanya seperti, Who Are We? The Chalennges to America's National Identity (New York: Simon \& Schuster, 2004). J uga "Political Modernization: America vs Europe," World Politics, 18, 3 (1966), dan Gelombang Demokratisasi Ketiga, terjemahan, (J akarta: G rafiti, 1995). 
Suatu pengujian ketat terhadap proses kontak budaya dalam sejarah dunia mengungkapkan suatu pola polarisasi yang menyolok antara Timur dan Barat. Di Timur, kontakkontak budaya pada umumnya berlangsung melalui cara-cara damai. Misalnya, budaya-budaya Islam yang pertama kali dibawa masuk ke Indonesia oleh orang-orang Arab dan India di abad ketujuh dan memuncak di abad ketiga belas. Kedatangan mereka ke kepulauan Indonesia menstimulasi pertukaran budaya antara bangsa-bangsa yang berbeda ini.

Sebaliknya, di Eropa, kontak-kontak budaya pada umumnya melibatkan peperangan, invasi, kolonisasi dan pencaplokan wilayah. Ini diilustrasikan oleh ekspansi-ekspansi sang imperialis dari kekuatan-kekuatan Barat di Asia dan Afrika antara abad ke 16 dan abad ke 19 yang mengarah ke peperangan, invasi dan kolonisasi Asia Tenggara dan Afrika. Ia juga menimbulkan perubahan-perubahan budaya, sosial, politik dan ekonomi secara radikal di Asia dan Afrika.

Islam sendiri nampaknya menyadari bahwa penyebaran agama tidak selamanya harus melalui asimilasi budaya. Seringkali agama harus tersebar melalui sebuah 'komunitas' dan melampaui fase-fase, dan bukan hasil dari sebuah peristiwa tunggal atau karya dari seorang individu dalam sebuah situs tertentu. Penyebaran dari sebuah agama adalah sebuah proses penyebarluasan secara bertahap di kalangan sekelompok orang, sebuah komunitas atau sebuah suku di suatu periode waktu.

Sementara itu, teori-teori yang Eropa-sentris banyak pula yang tidak meremehkan vitalitas dari budaya asli maupun budaya asing. Peter Burke cenderung untuk menyatakan bahwa 'di masa lalu, dampak dari perubahan budaya telah diperlunak oleh daya tahan yang gigih dari budaya lama yang berdiri berdampingan dengan budaya baru. Masing-masing dari budaya baru hampir selalu diterima secara sepenuh hati oleh sebagian besar masyarakat'.2

Dengan demikian, kita melihat bahwa kemunculan sebuah peradaban dalam sebuah peradaban atau masyarakat semestinya tidak menyapu bersih praktik-praktik dan nilai-nilai budaya asli. J ustru sebaliknya, budaya-budaya pendatang seharusnya melebur dan bahkan terlokal-kan. Dan inilah salah satu tujuan yang ingin diperjuangkan oleh Gulen dan Ramadhan.

\section{Pengertian B udaya}

Para pakar sosiologi dan antropologi telah mengajukan sejumlah definisi tentang konsep kebudayaan, yang dapat digunakan sebagai basis bagi analisa sejarah, antropologi sebagaimana juga digunakan untuk analisa sosiologis.

Clyde Klukhohn, seorang antropolog, telah mendefinisikan kebudayaan sebagai berikut: (1) cara menyeluruh tentang kehidupan suatu masyarakat; (2) warisan sosial yang diperoleh individu dari kelompoknya; (3) suatu cara berpikir, merasa, dan meyakini; (4) sebuah abstraksi dari perilaku; (5) suatu teori yang menjadi bagian dari pakar antropologi tentang cara di mana suatu kelompok berperilaku; (6) sebuah rumah penyimpanan dari sejumlah hasil proses pembelajaran; (7) seperangkat orientasi yang di-standarisasikan bagi masalah-masalah yang terjadi; (8) perilaku yang dipelajari; (9) sebuah mekanisme bagi regulasi perilaku normatif; (10)

${ }_{2}^{2}$ Peter Burke, Popular Culture in Modern Europe (London: Maurice Temple Smith, 1978), 23. 
seperangkat teknik-teknik untuk penyesuaian bagi lingkungan eksternal dan bagi orang-orang lain; dan (11) sebuah endapan sejarah. ${ }^{3}$

Di tengah-tengah penyebaran luas teori ini, seorang pakar antropologi yang terkenal, Clifford Geertz, bersetuju dengan Max Weber yang meyakini bahwa manusia adalah hewan yang terjerat dalam jejaring makna yang telah dia rajutsendiri. Ia meyakini bahwa budaya adalah 'jejaring makna yang menjerat manusia itu, dan analisa tentangnya dengan demikian bukan sebuah sains eksperimental yang meneliti tentang hukum tapi sesuatu yang bersifat interpretatif yang meneliti tentang makna'. ${ }^{4}$

Di sisi lain, para pakar sosiologi melihat kebudayaan dan masyarakat sebagai dua hal yang saling terkait satu sama lain. Anthony Giddens mendefinisikan kebudayaan sebagai terdiri dari 'nilai-nilai yang dianut oleh anggota-anggota sebuah kelompok yang diandaikan, normanorma yang mereka ikuti, dan benda-benda materi yang mereka kreasikan'. ${ }^{5}$ Dia telah mengelaborasi bahwa konsep kebudayaan mengacu pada cara kehidupan dari anggota-anggota suatu masyarakat, atau dari kelompok-kelompok dalam sebuah masyarakat, yang mencakup seni, sastra, musik, seni lukis, pakaian, tradisi-tradisi perkawinan dan kehidupan keluarga, polapola kerja, upacara-upacara agama, target-target kesenangan yang ingin diraih, dan benda-benda yang dihasilkan. ${ }^{6}$

Singkatnya, budaya mengacu pada cara kehidupan dari sebuah masyarakat, yang mencakup kode-kode dari sopan santun, pakaian, bahasa, seni-seni, ritual-ritual, norma-norma perilaku, agama, makanan, ideologi, pandangan dunia, filosofi kehidupan, mengolah dan memproduksi benda-benda, dan lain-lain. Secara esensial, budaya dari sebuah masyarakat atau sebuah kelompok mencerminkan identitas atau etnisitasnya.

Dalam kaitan dengan model teori tentang kontak budaya, adalah sulit untuk menemukan sebuah teori yang spesifik yang dapat diikuti secara persis. Namun, teori dan konsep yang umum tentang kontak budaya yang telah dikembangkan oleh banyak pakar antropologi dan sosiologi memang sangat berguna. Anthony $\mathrm{G}$ iddens ${ }^{7}$ misalnya, menawarkan suatu perspektif sosiologis yang jauh lebih luas bagi seseorang untuk melihat pada kontak budaya dan hasil-hasil akhir mereka. Peter Berger pada sisi lain, mempertahankan pendapat bahwa dua budaya yang saling berkontak tidak selalu menghasilkan konflik, tapi mungkin sekali terjadi fusi antara keduanya. Namun demikian, hasil akhirnya bergantung pada kekuatan dari dua budaya itu. ${ }^{8} \mathrm{~J}$ ika budaya A lebih kuat dari pada budaya $B$, maka hasil akhirnya cenderung untuk mendukung karakterkarakter budaya A. Namun, jika dua budaya itu sama kuatnya, maka kedua karakter dari budaya A dan budaya B akan dipertahankan. Donald J ohnson juga berargumentasi sejalan dengan argumentasi ini. Dia berpendapat bahwa kontak budaya akan menghasilkan keterpecahan atau

\footnotetext{
${ }^{3}$ Dikutip oleh Clifford Geertz, Islam O bserved: Religious Development in Morocco and Indonesia (Chicago and London: The University of Chicago Press 1971), 4.

${ }^{4} \mathrm{Ibid}, \mathrm{s}$.

${ }^{5}$ Anthony Gidden, Central Problem in Social Theory: Action, Structure, and Contradiction in Social Theory (Hongkong: McMillan Education, 1990), 31.

${ }^{6} \mathrm{lbid} ., 5$.

${ }^{7}$ lbid.

8 Peter B erger, Langit Suci: Agama Sebagai Realitas Sosial, terjemahan (J akarta: LP3ES, 1991).
} 
fusi. Namun demikian, dia mengemukakan sebuah pola asimilasi dan dua variabelnya sebagai hasil dari kontak budaya: penggabungan $(A+B=C)$ dan inkorporasi [disatukan dan dibentuk menjadi satu kelompok] $(A+B=A) .{ }^{9}$

Namun, teori-teori atau konsep-konsep di atas tentang kontak budaya adalah terlalu sederhana, ketika mereka tidak memperhitungkan kompleksitas dari situasi sosio-politik dan situasi wilayah. Sikap dari kelas yang berkuasa tampaknya menjadi penting dalam menentukan perubahan budaya. J ika elite penguasa menerima budaya baru, maka penyebaran dari budaya baru ini akan menjadi lebih mudah, tapi jika elite penguasa menolaknya, maka budaya baru ini tidak mungkin untuk berkembang. Sebagai tambahan, produk dari kontak budaya ini juga lebih kompleks dari pada yang biasa dikemukakan; ia tidak selalu sebuah fusi yang seimbang.

Inilah yang menjadi tantangan ketika kita mengangkat masalah kebersandingan budaya antara Islam, yaitu budaya yang dibawa oleh orang-orang Islam dari tempat aslinya masingmasing, dengan budaya Eropa. Yang nampak jelas selama ini adalah bahwa walaupun budayabudaya Islam yang dibawa oleh kaum pendatang Muslim di Eropa mampu -pada tingkatan tertentu- untuk melebur ke dalam budaya Eropa, namun permasalahannya adalah peleburan itu tidak selamanya bersifat seimbang. Artinya, kadang-kadang orang Muslim dari Indonesia umpamanya harus mengorbankan sisi-sisi tertentu dari budayanya untuk bisa melebur ke dalam masyarakat Eropa. Masalahnya akan jauh lebih komplek ketika peleburan itu berkaitan dengan agama, baik secara langsung maupun tidak, jilbab umpamanya. Bagi sebagian kaum Muslim, jilbab adalah kewajiban agama yang tidak bisa ditawar-tawar. Tapi masalahnya adalah bahwa masyarakat Eropa sebagian besar tidak mau melihat budaya jilbab tumbuh di sana. Akibatnya, proses peleburan budaya tidak berjalan dengan mulus. Dan kadang kala, ada unsur pemaksaan dalam proses peleburan itu. Inilah kenapa bahwa peleburan budaya tidak sesederhana yang dibayangkan oleh banyak orang.

Namun terlepas dari kompleksitas yang muncul dari proses peleburan budaya ini, apa yang ditawarkan oleh Gulen dan Ramadhan patut disimak. Keduanya memiliki tujuan yang nyaris sama, tapi mengembangkan metode yang berbeda.

\section{Gulen dan Tawaran Praktisnya tentang Kebersandingan Budaya}

Gulen lahir di Turkey pada tanggal 27 A pril 1941. Sekarang dia tinggal di Amerika dan masih aktif sebagai penulis dan pemimpin gerakan $G$ ulen yang berskala internasional. Dia telah menulis 60 buku, yang salah satunya telah diterjemahkan ke dalam Bahasa Indonesia, berjudul Kunci-kunci Rahasia Sufi, terbitan tahun 2001.

Bagi banyak orang, Gulen dipandang sebagai tokoh dengan pandangan-pandangan yang moderat. Tapi banyak pula yang menuduhnya sebagai kepanjangan tangan dari Mustofa Kemal Ataturk dengan sekulerismenya yang ingin mengebiri Islam dari kehidupan politik di Turkey.

Gulen mendirikan gerakan Gulen yang bergerak di bidang pendidikan. Ratusan sekolah dan 6 universitas telah ia dirikan di Turkey dan di beberapa negara Islam bekas jajahan Uni Soviet. la juga telah mendirikan beberapa stasiun radio dan koran serta majalah Zaman sebagai

${ }^{9}$ Donald J ohnson, Teori Sosiologi Klasik dan M odern I-II, terjemahan (J akarta: G ramedia, 1988). 
media komunikasi dengan masyarakat luas.

Karena alasan politik di Turkey, Gulen pindah ke Amerika Serikat. Pada tahun 1980 ia terlibat dalam kudeta militer. Tahun 1997 juga terlibat dalam soft coup untuk menumbangkan pemerintahan Islamist pimpinan Perdana Menteri Necmettin Erbakan. Erbakan akhirnya tumbang. Sejak saat itu, Gulen sering mendapat ancaman dari kaum Islamist dan memaksanya untuk lari ke Amerika Serikat pada tahun 1998.

Kebesaran nama Gulen sudah tidak bisa diragukan lagi. Pemerintah Amerika Serikat pernah menyebutnya sebagai "orang asing yang memiliki kemampuan luar biasa". Mass media di sana pun -dan juga di berbagai belahan dunia lainnya- memandang Gulen sebagai sosok yang penting dan berpengaruh. Tabloid The Guardian Inggris pada edisinya hari Senin 23 J uni 2008 menempatkan Gulen sebagai pemimpin Muslim nomer satu dunia berdasarkan voting yang dilakukannya bekerja sama dengan majalah Prospect yang juga terbit di Inggris. The Guardian menulis pada edisi itu bahwa Gulen adalah "Islamic Scholar Voted World's no 1 thinker".

Bukan hanya The Guardian yang secara umum bercirikan sosial dan politik, majalah ekonomi AS Forbes pun mengakui kebesaran Gulen. Pada edisinya tanggal 21 J anuari 2008, majalah ini menulis pada liputannya tentang Gulen, "Gulen is a pronvincial Turkish preacher who has inspired a worldwide network of Muslim". Bagi majalah ini, Gulen adalah "sosok yang mendorong para pengikutnya untuk tidak bertindak subversif kepada sekulerisme dan modernitas, tapi mendorong mereka untuk memaksimalkan potensi yang mereka miliki untuk kemajuan bersama". Selanjutnya Forbes juga menulis bahwa salah satu ajaran Gulen adalah "untuk tidak menentang modernitas tapi ikut terlibat di dalamnya dan mencari ispirasi dari teks-teks suci dalam proses keterlibatan itu".

Harian International H erald Tribune melakukan hal sama dengan Forbes. Tiga hari sebelum Forbes memuat berita tentang Gulen tepatnya tanggal 18 J anuari 2008, harian ini mengakui semua hal yang sama dengan Forbes.

Majalah AS Foreign Policy pada edisinya bulan Agustus 2008 menulis bahwa G ulen adalah "tidak dapat diragukan lagi merupakan pemimpin dunia Islam kelas satu". Itu kemudian diamini oleh majalah mingguan yang terbit di Pakistan The Cutting Edge yang pada edisinya tanggal 15-21 O ktober 2008 yang menulis bahwa Gulen adalah "ikon perdamaian dunia".

Selama karir intelektualnya Gulen telah banyak memberikan perhatian kepada masalah kebersandingan budaya terutama antara budaya Islam dan Eropa. Kebetulan Turkey bertetangga dengan Eropa, dan banyak orang Turkey yang menetap di Eropa. Hal ini menimbulkan banyak persoalan yang dialami oleh orang-orang Turkey yang menetap di Eropa. Orang Turkey banyak yang hijrah ke German, dan di sana generasi Turkey seringkali berhadapan dengan persoalan kebersandingan budaya.

Pandangan Gulen tentang kebersandingan budaya dapat dianggap sebagai tawaran dari pihak Muslim tentang persoalan ini. Tawaran dari Eropa memang sangat beragam mulai dari yang bernada positif hingga yang negatif. Berkaitan dengan tawaran Eropa, menarik untuk mengamati karya-karya Rudolf Siebert dan Bryan Turner. Siebert berpendapat bahwa dalam melihat masalah ini hendaknya kita menggunakan pendekatan sejarah. Artinya, untuk memaknai apa yang sekarang kita alami, kita harus terlebih dahulu mengetahui apa yang pernah terjadi 
dalam sejarah. ${ }^{10}$

Pendekatan ini nampaknya bermaksud mengingatkan kembali apa yang pernah terjadi di masa lalu antara kaum Muslim dan kaum Kristen Eropa di mana sering terjadi peperangan dan ketegangan. Oleh karena itu, pendekatan ini jika diterapkan kecil kemungkinan akan dapat membawa hasil yang positif.

Namun mungkin juga bahwa apa yang dimaksudkan oleh Siebert adalah hendaknya kita belajar dari masa lalu dengan memilah-milah mana yang dapat diterapkan dan mana yang harus ditinggalkan. Masa lalu terdiri dari kegagalan-kegagalan dan juga kesuksesan-kesuksesan. Apa yang merupakan kegagalan di masa lalu haruslah ditinggalkan dan apa yang merupakan kesuksesan di masa lalu dapat diambil dan dicontoh.

Apapun maksud Siebert, pendekatan ini tidak disetujui oleh Gulen. Dalam konsepnya, Gulen mengajak agar pihak Muslim maupun Eropa sama-sama melupakan masa lalu dan siap untuk melangkah ke masa depan. Dalam hal kebersandingan budaya ini, Gulen memandang bahwa masa lalu adalah kelam sehingga harus dilupakan. ${ }^{11}$

Sementara itu Turner -bicara tentang kontak budaya dan perubahan budaya- berpendapat bahwa kontak budaya merupakan sebuah faktor penting dalam perubahan budaya dalam seluruh kehidupan manusia di muka bumi ini. Interaksi dengan kelompok-kelompok dari ras manusia membuat suatu masyarakat atau komunitas terbuka bagi masuknya budaya baru, praktik-praktik dan ide-ide baru. Hasil-hasil dari interaksi dengan dunia luar ini menimbulkan banyak perubahan besar dalam semua konteks budaya. Di samping memperkenalkan unsur-unsur baru, interaksi juga menimbulkan perubahan-perubahan budaya dalam sebuah masyarakat. Agar supaya unsurunsur baru yang dibawa dari luar ini dapat diadopsi dan diintegrasikan ke dalam suatu sistem masyarakat, perubahan-perubahan harus terjadi dalam sistem itu guna mengakomodasi kualitaskualitas dan karakter-karakter yang baru. ${ }^{12}$

Pandangan ini bersifat mengilhami bahwa interaksi budaya harus dilakukan. Dan mungkin atas dorongan orang-orang semacam Turner inilah, dunia Barat nampaknya telah membuat kemajuan signifikan dalam hal interaksi budaya terutama dengan dunia Islam. Dialog-dialog lintas budaya dan agama telah banyak dilakukan dan didukung oleh dunia Barat guna lebih mendekatkan antara Islam dan Barat.

Di samping kedua orang ini dengan pandangan yang mereka tawarkan ada pula kajiankajian lain untuk mengembangkan model-model bagi mekanisme dan kontak budaya dan prosesproses perubahan budaya. Kajian-kajian ini berkisar pada pengenalan model-model sebagai pola yang kita berlakukan pada dunia nyata ini, sadar atau tidak, agar dapatmemahami fenomena

\footnotetext{
${ }^{10}$ Rudolf Siebert, The Critical Theory of Religion: From Universal Paradigm to Political Theology (Berlin, New York, Amsterdam: Mouton Publishers, 1985), 5.

${ }^{11}$ Sevket Yavuz dan Davut Ayduz, "Turning from Doom-Laden Soothsayings to Mutual Communication and Wisdom (Ta'aruf)", dalam Peaceful C oexistence: Fethullah Gülen's Initiatives in the Contemporary World, editor Ihsan Y ilmaz et al. (Inggris: Leeds Metropolitan University Press, 2007), 94. J uga EfratE Aviv, "The Light of Tolerance Between Rabbi Abraham Kook and H oja Efendi Fethullah Gulen", dalam Peaceful Coexistence: Fethullah Gülen's Initiatives in the Contemporary World, 107-110.

${ }^{12}$ Bryan Turner, Sosiologi Islam, Suatu Telaah Analitis atas Tesa Sosiologi Weber, terjemahan (J akarta: Rajawali, 1984).
} 
yang beragam ini. Kajian-kajian ini juga menggunakan suatu model sistem-sistem yang umum guna menghadirkan budaya secara menyeluruh.

Dari berbagai tawaran yang dikemukakan oleh Siebert dan Turner serta beberapa kajian di bidang budaya, dapat diambil sebuah kesimpulan bahwa menurut mereka budaya dalam pengertian yang lebih luas adalah sebuah sistem yang mencakup jumlah teori yang tak terbatas dari subsistem-subsistem yang saling berhubungan dengan cara bahwa perubahan apapun dalam satu subsistem mengharuskan penyesuaian kembali secara sistematis dari semua subsistemsubsistem lain sehingga keseimbangan dari sistem itu dapat dipertahankan.

Tesa ini menunjukkan adanya keterkaitan yang erat antara proses-proses sosial, agama, ekonomi dan politik dalam mekanisme interaksi budaya. Itulah sebabnya kenapa proses interaksi budaya ini bukanlah hal yang mudah karena melibatkan hampir seluruh aktifitas dan aspek kehidupan manusia. Proses ini juga membutuhkan adanya struktur sosial dari setiap budaya yang terlibat dalam interaksi, kegiatan-kegiatan memberi, menerima dan pertukaran, yang semuanya mempunyai fungsi-fungsi sosialnya masing-masing.

Gulen menyadari kompleksitas itu. Makanya ia mulai memikirkan masalah interaksi budaya sejak 50 tahun yang lalu dan masih konsisten memikirkan hal itu. Salah satu tawaran yang ia ajukan adalah bahwa pada tingkat perilaku individu, setiap Muslim jika siap berinteraksi dengan budaya Barat harus membenahi perilakunya, memperbaiki moral dan kejiwaannya. Seorang Muslim harus hormat pada orang lain, pada budayanya dan menghargai perbedaan-perbedaan yang ada di masyarakat. ${ }^{13}$

Ini adalah ajaran Tasawuf yang diselipkan dalam misi besar Gulen untuk melakukan interaksi budaya. Gulen sendiri adalah seorang Sufi yang mewarisi ide-ide Said Nursi (18761960) yang juga orang Turkey. Sejak tahun 1957, Gulen telah mulai mempelajari ide-ide Nursi dan terpengaruh olehnya. Ide Nursi tentang modernitas diambil oleh Gulen dan dikembangkan lebih lanjut. Ajaran bahwa Muslim tidak menjauhkan diri dari modernitas adalah ajaran Gulen yang berasal dari Nursi.

Bukunya Kunci-kunci Rahasia Sufi memuat ajaran-ajaran Tasawuf yang nampaknya ia maksudnya sebagai landasan praktis untuk menghadapi masalah ini. ${ }^{14}$ Sekilas buku ini tidak jauh berbeda dengan buku-buku tasawuf lainnya. la juga bicara soal kesabaran, zuhud, takwa, kejujuran tawadu' dan yang sejenisnya yang merupakan ajaran inti tasawuf praktis. Tapi pembacaan yang lebih mendalam menunjukkan bahwa sebenarnya buku ini dimaksudkan sebagai landasan praktis bagi kaum Muslim untuk dapat menjalani kehidupan sosialnya dengan baik. Inti dari misi buku ini dengan demikian adalah mengajak sesama Muslim untuk "bertindak tanduk sesuai dengan suri tauladan $\mathrm{Nabi}^{15}$

Implikasi dari ajakan ini adalah bahwa seyogyanya seorang Muslim berakhlaq al-karimah seperti yang telah dicontohkan oleh sang Nabi di antaranya dengan berperilaku dalam masyarakat dengan baik dan sopan, menghormati hukum yang ada, menghargai pendapat orang lain dan

${ }^{13}$ Thomas Michel, "Fethullah Gulen, Following in the Footsteps of Rumi", dalam Peaceful Coexistence: Fethullah Gülen's Initiatives in the Contemporary World, 183-189.

${ }^{14}$ Fethullah Gulen, Kunci-kunci Rahasia Sufi, terjemahan (J akarta: Srigunting, 2001).

15 Ibid., 3. 
tidak melakukan kerusakan di tengah-tengah masyarakat tempat ia hidup.

Bagi Gulen, Tasawuf juga mencari kebaikan dan kehormatan tertinggi, yaitu Allah dengan terlebih dahulu menjadi baik dan hormat pada kehidupan duniawi. ${ }^{16} \mathrm{~J} \mathrm{ika} \mathrm{ini} \mathrm{dimaknai} \mathrm{dalam}$ bingkai kebersandingan budaya, maka itu berarti bahwa proses kebersandingan ini hanya bisa berjalan jika pihak Muslim berlaku baik dan terhormat. Maka tidak salah jika buku tersebut dapat kita maknai sebagai pedoman praktis dan moral bagi Muslim untuk dapat siap terjun di dunia nyata dengan keberagaman yang ada, siap menghadapi modernitas, dan melakukan interaksi dengan budaya, peradaban dan bangsa-bangsa lain.

Bagi sebagian kalangan akademis, mungkin tawaran praktis Gulen tersebut terkesan naif. Sebab dalam dunia akademis biasanya kita bicara pada tataran wacana. Bahkan kalangan akademis ada yang melulu mempercayai bahwa apa yang terjadi di lapangan berupa ketegangan sosial, konflik politik, benturan budaya dan sejenisnya adalah cerminan dari cara pandang kita sebagai manusia. Oleh karena itu, untuk merubah kenyataan sosial tersebut haruslah dimulai dengan merubah cara pandang itu. Dan untuk melakukan itu harus dilakukan pada tataran wacana. Perilaku seseorang adalah cerminan pikirannya. Untuk mengatur perilakunya dengan demikian, harus dimulai dengan mengatur pikirannya.

Mungkin itu benar, dan Gulen juga sebenarnya bicara pada tataran wacana teoritis tentang kebersandingan budaya yang nanti akan kita singgung. Tapi, tawaran praktis ini tidak dapat dikesampingkan begitu saja, karena ketegangan sosial di Eropa tidak selamanya terjadi karena cara pandang orang Muslim terhadap Eropa atau sebaliknya. Seringkali ketegangan terjadi justru karena kekeliruan salah satu pihak dalam berperilaku sehingga menimbulkan ketegangan dan kemudian konflik. Banyak pula terjadi saling menyerang semata-mata karena kecemburuan etnis dan lain sebagainya.

Oleh karena itu, Gulen menyadari bahwa untuk dapat mengawali terjadinya proses kebersandingan budaya di Eropa dengan baik, terlebih dahulu ia harus memastikan bahwa secara kepribadian dan tingkah laku, orang Muslim sudah siap. Barulah kemudian masuk ke wilayah wacana dan teori.

\section{Wacana Gulen}

Sebagai seorang aktifis dan pemikir, Gulen terbukti mampu mempengaruhi banyak orang melalui kegiatan-kegiatan sosial dan ide-idenya. Bahkan selama dua tahun terakhir ini tidak kurang dari 10 seminar bertaraf internasional diadakan untuk mengkaji pemikirannya dan menghargai upaya-upayanya dalam menciptakan perdamaian dunia melalui dialog-dialog lintas agama dan lain sebagainya.

Seminar-seminar yang diadakan itu biasanya membahas masalah kontribusi Gulen di bidang hubungan Barat dan Timur, Utara dan Selatan, demokrasi, multikulturalisme, glo balisasi, kewarganegaraan dan dialoq lintas budaya serta agama dalam konteks modernitas. Ide-idenya bahkan telah pula menarik perhatian Vatikan untuk mengundangnya dan melakukan dialog dengan otoritas gereja Katolik tertinggi di dunia itu. Di Turkey, ide-idenya juga telah

\footnotetext{
${ }^{16} \mathrm{Ibid}$.
} 
mempengaruhi pemegang kekuasaan dan para pengambil kebijakan untuk menentukan arah policy yang sesuai dengan semangat toleransi dan kebersamaan.

Di Eropa, nama Gulen sudah tidak asing lagi apalagi ide-idenya pada tataran praktis sudah banyak diikuti oleh para generasi muda di sana. Ketika kasus-kasus berbau SARA baru-baru ini terjadi di Eropa, nama Gulen semakin terkenal karena di samping sudah populer sebelumnya, Gulen kemudian menjadi rujukan dalam mensikapi kasus-kasus tersebut. Masih segar di ingatan kasus pembunuhan Theo van Gogh, anggota parlemen Belanda radikal sayap kanan, pidato Paulus di Regensburg yang sangat kontroversial yang menuduh Islam sebagai agama yang disebarkan menggunakan pedang, dan kasus kartun di Swedia yang mengejek Nabi. Posisi Gulen menghadapi kasus-kasus itu tegas, yaitu tetap mengedepankan dialog dan menghormati pendapat orang lain tanpa harus mengorbankan keyakinan agamanya.

Sikap ini menumbuhkan rasa hormat kepadanya baik dari kalangan Muslim sendiri maupun kalangan Eropa. Dengan demikian, di tengah ketegangan semacam itu, nampaknya ia berhasil menanamkan dan menumbuhkan semangat perdamaian universal untuk menciptakan rasa aman bagi setiap warga dari ras dan agama-agama yang berbeda.

Sekilas memang kasus-kasus di atas terkesan merugikan Islam dan kaum Muslim. Tapi dengan kematangan pikir dan kebaikan hatinya, justru Gulen memanfaatkannya untuk menunjukkan bahwa Islam adalah agama yang cinta damai. Seminar-seminar yang gencar diadakan belakangan ini tentang Gulen, yang di antaranya disponsori oleh House of Lord di Inggris dan diadakan di dalam gedung parlemen Inggris, adalah upaya untuk mengcounter tuduhan-tuduhan miring tentang Islam tapi dengan cara yang apik, santun, damai dan bermuatan ilmiah.

Terkadang dalam menyikapi kasus-kasus semacam itu, Gulen dan para pengikutnya terkesan kritis terhadap tradisi pemikiran Islam sendiri. Misalnya, dalam seminar tersebut di atas yang mengambil tema "Peaceful Co-Existence: Fethullan Gulen's Initiatives in the Contemporary World" didegung-dengungkan slogan bahwa Islam tidak identik dengan Arabisme, Pakistanisme, Turkisme atau yang lainnya tapi identik dengan keadilan dan kesetaraan. Slogan itu untuk yang ke sekian kalinya menekankan universalitas Islam dan menolak pereduksian Islam ke dalam konteks yang sempit, lokalistik dan sangat terbatas. O leh karena itu - dan ini merupakan implikasi logis dari pandangan tersebut- apapun yang menjadi sifat, budaya, tradisi dan kebudayaan negara tertentu yang kebetulan mayo ritas penduduknya adalah Muslim, belum tentu merupakan ajaran Islam atau mewakili salah satu aspek dari dogma Islam.

Pandangan itu sejalan dengan semangatal-Afghani, Muhammad Abduh dan Rashid Ridha untuk mempertemukan Islam dengan modernitas. Bagi mereka, Islam hendaknya dipandang memiliki kekuatan integratif yang tinggi yang dapat beradaptasi dengan berbagai macam kondisi, budaya dan peradaban.

Mendobrak mentalitas lokalistik kaum Muslim memerlukan penataan ulang perspektif kita tentang agama yang kita anut. Oleh karena itu proyek besar pemikiran Gulen adalah melakukan penataan ulang itu.

Namun Gulen juga sadar bahwa penataan ulang perspektif itu juga harus dilakukan oleh pihak-pihak yang ingin melakukan interaksi budaya dengan kaum Muslim. Eropa umpamanya, 
jika serius ingin terlibat dalam interaksi budaya dengan kaum Muslim harus pula melakukan penataan ulang terhadap perspektifnya tentang agama yang mereka anut juga terhadap Islam yang selama ini seringkali mereka pandang dari kaca mata yang negatif. Penataan ulang perspektif ini oleh sebagian pengamat kajian tentang G ulen disebut Discursive Parallel Arenas, ${ }^{17}$ semacam tindakan yang dilakukan secara bersamaan oleh semua pihak yang terlibat dalam proyek tertentu dalam memperbaik perspektifnya. Termasuk dalam penataan ulang perspektif kita tentang Islam adalah upaya membaca dan memahami kembali pengertian identitas keislaman kita dalam konteks modernitas dan ke-Eropaan, bagi mereka yang tinggal di Eropa.

Masalah identitas ini termasuk masalah yang sangat sering muncul dalam perdebatan baik di Eropa maupun di negara-negara Islam yang memiliki perhatian khusus terhadap persoalan tersebut. Di Eropa, orang-orang Islam juga banyak yang terlibat dalam upaya pendefinisian kembali idenitas ke-Eropaan orang Eropa, seperti yang dilakukan umpama oleh Masood A hmed, seorang Muslim keturunan Pakistan yang sekarang bekerja di Kementerian Dalam Negeri Inggris. Ziauddin Sardar dalam kadar tertentu juga terlibat dalam proyek ini.

Bagi orang Eropa sendiri, Islam sering dijadikan sebagai sumber keresahan apalagi jika Islam muncul ke public space sebagai agama dengan identitas keagamaannya yang kental. J ilbab sering menjadi sumber keresahan, karena jilbab menyimbolkan identitas agama yang kuat.

Di Eropa, statemen bahwa Islam terus berkembang juga dapat dirasakan di mana-mana. Kaum Muslim terus membangun sekolah-sekolah Islam, tempat-tempat ibadah, dan bahkan media massa berbasis Islam. Wanita berjilbab juga banyak.

Dengan semakin banyaknya jumlah ummat Islam di Eropa, mereka juga kini turut andil dalam membentuk sejarah Eropa. Mereka ikut memainkan peran simbolik dalam menentukan identitas Eropa dengan terlibat dalam perbincangan-perbincangan serius melalui mass media dan yang sejenisnya. Dengan demikian, keberadaan ummat Islam di Eropa tidak hanya bersifat geografis dan demografis, tapi juga bersifat simbolis dan fungsional.

Tapi semakin luas peran ummat Islam di Eropa, semakin besar pula keresahan Eropa terhadap Islam. Buktinya setiap kali ada public debate tentang Islam isu-isu tentang kekerasan, pelanggaran $\mathrm{HAM}$, toleransi beragama, kesetaraan gender, demokrasi dan yang sejenisnya selalu muncul dan dipertanyakan. Islam sering dituduh tidak sejalan dengan Eropa dalam hal-hal ini. Mungkin itu benar, karena buktinya banyak negara Muslim yang tidak demokratis dan lain sebagainya. Bahkan al-Qur'an pun terdapat banyak ayat yang kalau dibaca dari kaca mata Barat terkesan "diskriminatif" terhadap wanita dan orang-orang non-Muslim.

J awaban Gulen terhadap itu semua adalah dengan mengatakan bahwa Islam bukanlah politik, tapi personal pietism. ${ }^{18}$ Artinya, perdebatan tentang hal-hal tersebut di atas sarat dengan nuansa politis dan selayaknya dihindari karena akan semakin memperuncing perbedaan antara Islam dan Barat.

\footnotetext{
${ }^{17}$ Kate Kirk dan G urkan Celik, "O pening the Road to Dialogue: an Amalgamation of Gulen's and Spinoza's sdeas on Tolerance and Dialogue Applied to the Situation of Muslims in the Netherlands", dalam Peaceful Coexistence: Fethullah Gülen's Initiatives in the Contemporary World, 180-183.

${ }^{18} \mathrm{~N}$ azila Isgandarov, "Identity as a M ajor Factor in Integration to the Western Society", dalam Peaceful Coexistence: Fethullah Gülen's Initiatives in the Contemporary World, 228.
} 
Ini mungkin salah satu dari kelemahan Gulen. Ia terkesan lari dari banyak persoalan yang justru bagi Eropa merupakan unsur penting dalam upaya menciptakan kesepahaman antara Islam dan Barat.

Tapi G ulen memiliki logikanya sendiri. Dengan personal pietism, ia juga bermaksud bahwa hendaknya kaum Muslim di seluruh dunia memperjuangkan Islam bukan melalui pintu politik tapi melalui pembangunan budi luhur atau akhlaq al-karimah dan bisa juga melalui jalur budaya. Oleh karena itu, Gulen menolak Islam Politik dan politisasi Islam seperti upaya mendirikan Khilafah Islamiyah, ${ }^{19}$ penerapan Shari'ah Islam dan yang sejenisnya.

Bagi Gulen, Islam adalah tatanan moral yang melandasi segenap kegiatan manusia termasuk politik. Ini artinya, bahwa politik hanya merupakan bagian kecil dari Islam dan bukan bagian satu-satunya.

Secara langsung, ini juga berarti bahwa Gulen menganut sebuah diskursus yang merupakan antitesa dari apa yang pernah diajarkan oleh beberapa tokoh pemikiran politik Islam era modern seperti al-Mawdudi dan al-Banna. Kedua tokoh ini menekankan sikap anti imperialisme dan westernisasi, menghendaki didirikannya Khilafah Islamiyah dan diterapkannya Shari'at Islam. Gulen menghendaki sistem demokrasi bagi negara-negara Islam, kebersandingan dan keharmonisan antara Timur dan Barat, pluralisme, dan penegakan hak asasi manusia.

\section{Wacana Diskursif Ramadhan}

Ide Gulen ini didukung oleh Tariq Ramadhan, seorang pemikir Muslim kelahiran Geneva yang kebetulan merupakan cucu al-Banna. J ika secara biologis Ramadhan adalah keturunan al-Banna, maka secara pemikiran nampaknya al-Banna dan Ramadhan adalah seperti David dan G oliath. Ini mungkin biasa dalam sejarah pemikiran Islam. B ahkan antara U mar bin Khattab dan putranya Abdullah bin U mar bin Khattab terdapat perbedaan-perbedaan yang sangat tajam dalam hal istimbat,al-ahkam. Umar sangat rasional sementara putranya sangat konservatif.

Ramadhan memulai perjalanan karir keilmuwannya dengan mempelajari filsafat, dilanjutkan dengan sastra Perancis, ilmu-ilmu sosial lalu kajian keislaman. la merupakan penasihat agama dan sosial bagi berbagai pemerintahan di Barat dan di dunia Islam. Pada tanggal 6 Nopember 2008 kemarin, ketika berlangsung dialog lintas agama di Vatikan antara ummat Islam dan Katolik, ia ikut menjadi anggota delegasi Muslim yang mewakili Islam. Delegasi Katolik dipimpin oleh Paus Benediktus XVI, sedang delegasi Muslim dipimpin oleh Mustafa Ceric, Pemimpin Komunitas Muslim di Bosnia.

Di mata banyak orang, Ramadhan adalah tokoh pemikir Muslim yang lincah. J ohn L. Esposito dan J ohn 0. Voll pernah menyebutkan bahwa Ramadhan termasuk generasi baru pemikir Muslim yang “melanjutkan budaya tajdid yang maju dalam Islam. Ia membangun jaringan kaum modernis Muslim dan asosiasi pemikir Muslim dengan gaya yang baru. Pada saat yang sama, ia ingin melampaui tradisionalisme yang banyak dianut oleh para ulama konservatif yang tersebar di banyak dunia Islam. ${ }^{20}$

${ }^{19}$ Ibid., 215-227.

${ }^{20} \mathrm{~J}$ ohn L. Esposito and J ohn O. Voll, Makers of C ontemporary Islam (New York, Oxford U niversity Press, 2001), 20. 
Ramadhan mengajar di berbagai universitas terkemuka di dunia. Dalam berbagai tulisan dan paparannya, ia seringkali bicara soal Islam dan ummat Islam dalam kerangka budaya dan tradisi Eropa. la banyak menekankan pentingnya asimilasi budaya.

Banyak pula orang yang menuduh Ramadhan sebagai munafik dengan agenda terselubung. Apa yang ia lakukan adalah membahayakan bukan hanya bagi kelangsungan hidup Islam, tapi juga bagi validitas nilai-nilai universal seperti hak asasi manusia, pluralisme, dan demokrasi. J adi, bagi sebagian orang justu Ramadhan adalah anti demokrasi.

Seperti G ulen, Ramadhan menolak dikatakan sebagai Islamist. Baginya tidak penting label. Yang penting adalah bagaimana Barat dan Timur dapat mewujudkan persahabatan dan bukan permusuhan. Dalam kerangka ini, kolonialisme Barat dan westernisasi tidak ia lihat sebagai ancaman atau bahaya tapi sebagai kebaikan karena telah membawa banyak perubahan positif bagi dunia Islam. ${ }^{21}$

Kehadiran Ramadhan sendiri memang lumayan kontroversial. Tapi munculnya ke panggung pemikiran Islam modern telah banyak mewarnai wacana pemikiran keislaman dan membawa ide-ide baru yang menawarkan jawaban bagi generasi Muslim yang tinggal di Eropa.

Seperti Gulen, Ramadhan adalah seorang aktifis. Namun aktifisme Ramadhan berada di wilayah politik publik (bukan politik praktis), sedang Gulen di wilayah pendidikan dan sosial. Latar belakangnya sebagai seorang akademisi dan aktifis politik, membuat Ramadhan menjadi penulis yang diskursif. Jika Gulen memilih menggunakan bahasa-bahasa yang populer, Ramadhan memilih menggunakan bahasa-bahasa yang ilmiah dan teoritis.

J ika Gulen memasuki ranah kebersandingan budaya melalui pendidikan dan budaya, Ramadhan memasukinya melalui pintu perdebatan politik. Ramadhan seolah yakin bahwa untuk dapat berinteraksi dengan khalayak ramai di Eropa secara efektif, wacana politik adalah jalannya. Dalam melakukan agenda-agenda intelektualnya, Ramadhan nampaknya tidak memiliki kepentingan politik apapun selain ingin memperjuangkan kesetaraan sosial dan politik, keadilan dan demokrasi; sebuah misi yang juga ingin dicapai oleh Gulen.

Asimilasi budaya adalah kata kunci yang mendasari keseluruhan ijtihad pemikiran Ramadhan berkaitan dengan Islam di Eropa. Ramadhan juga menyerukan ijtihad untuk mencari solusi bagi berbagai persoalan yang dihadapi oleh ummat Islam di era modern ini. Karena pentingnya itu, Ramadhan dan tentunya Gulen tidak pernah lelah mengajak ummat Islam untuk ijtihad. ${ }^{22}$

Bagi Gulen, ijtihad bukan hanya upaya mereformulasi huku-hukum fiqih, tapi juga usaha ke arah penegasan kembali nilai-nilai universal Islam yang sekaligus merupakan nilai-nilai luhur kemanusiaan. Dunia Islam tegasnya, haruslah menggali kembali nilai-nilai kemanusiaan itu agar Islam dapat tampil di garis depan sebagai agama bagi seluruh ummat manusia. Ia menulis:

\footnotetext{
${ }^{21}$ Tariq Ramadan, To Be a European Muslim (Leicester: The Islamic Foundation, 1999), 96.

22 Pengertian ijtihad sangat luas. Tulisan ini tidak dapat terlalu jauh membahas masalah pengertian ijtihad tersebut. Untuk pembahasan lebih lanjut, lihat umpamanya Muhammad Q asim Zaman, The Ulama in Contemporary Islam: Ccustodians of Change (Princeton: Princeton University Press, 2002). J uga J ohn O. Voll, "Renewal and Reform in Islamic History: Taýjdid and Islah", dalam Voices of Resurgent Islam, J ohn L. Esposito (ed.) (New York: Oxford University Press, 1983), 32-47.
} 
“Kita sedang dalam proses pencarian kembali bagi kebangkitan akal dan juga hati, ruh dan juga pikiran. Sebuah upaya pembaharuan akan dapat dicapai jika dilandaskan pada kedua hal ini dan tentunya pada nilai-nilai luhur Islam yang manusiawi." ${ }^{23}$

Bagi Gulen, ummat Islam hingga saat ini masih kesulitan bersanding dengan bangsa, budaya dan peradaban lain, bukan hanya karena pola pikir mereka yang sempit tapi juga karena kondisi politik dalam negeri yang tidak mendukung. Upaya memahamkan ummat Islam tentang budaya lain menjadi sangat sulit karena umat Islam sendiri kadang masih terkendala untuk memahami budayanya sendiri. Bagi sebagian umat Islam, budaya-budaya yang berkembang di berbagai wilayah Muslim adalah budaya bobrok yang tidak perlu untuk dipahami.

Oleh karena itu, Gulen tidak segan mengkritisi kondisi internal umat Islam yang seringkali menjadi kendala bagi upaya mencapai kesepahaman budaya dengan Eropa. Ia menulis:

"Penindasan politik, perpecahan internal, penyalahgunaan lembaga-lembaga penelitian untuk mendapat dana, terlalu puas dengan sistem hukum yang sudah ada sehingga tidak ada upaya untuk mengembangkannya, penolakan terhadap pembaruan, dan keterbelakangan yang diakibatkan oleh sistem kekuasaan yang absolut dan tidak demokratis menjadi momok serius bagi ummat Islam di masa kini." 24

Ramadhan sepakat dengan Gulen. Dalam bahasa Ramadhan, ummat Islam masih tertutup untuk menerima budaya lain terutama budaya Eropa. B erhasil tidaknya sebuah asimilasi budaya tergantung pada apakah sebuah budaya itu tertutup atau terbuka untuk menerima unsur-unsur budaya lain.

Mental keterbukaan juga akan mengantarkan sebuah komunitas untuk mau melakukan kajian-kajian ilmiah guna mencapai sebuah konklusi obyektif tentang budaya lain. J ika umat Islam mau terbuka, maka mereka pastilah mau melakukan ijtihad untuk memahami budaya Eropa tentang berpakaian umpamanya, dan kemudian mau menilik ulang wajib tidaknya mengenakan jilbab bagi wanita Muslim. Perlu digarisbawahi bahwa jilbab di Eropa seolah sudah menjadi stigma, identik dengan radikalisme, fundamentalisme dan bahkan terorisme. Ini semua harus menjadi pertimbangan bagi umat Islam di Eropa untuk memaknai jilbab.

Ramadhan meyakini bahwa dengan semangat keterbukaan umat Islam akan lebih dapat menangkap ajaran-ajaran Islam yang bersifat universal dan tidak partikular. Di sini Ramadhan, seperti Gulen menekankan universalitas Islam dan mengajak umat Islam untuk tidak terjebak pada lokalitas budaya dan tradisi. Dengan keterbukaan pula, umat Islam akan dapat mengembangkan nilai-nilai universal itu agar selalu sejalan dengan tuntutan zaman. Istilah yang sering digunakan oleh Ramadhan adalah Islam's priorities, prioritas Islam. ${ }^{25}$ Prio ritas Islam adalah nilai-nilainya yang universal yang dapat merangkul tidak hanya tradisi Islam sendiri namun juga tradisi-tradisi lain dari agama dan budaya yang berbeda. Prioritas Islam dengan demikian adalah nilai-nilai yang inklusif yang jika diterapkan dalam dunia nyata akan dapat menampung di

${ }^{23}$ Farhod Alimuhamedov, "Peaceful Muslim-non-Muslim Co-existence in Secular Context", dalam Peaceful Coexistence: Fethullah Gülen's Initiatives in the Contemporary World, 378.

${ }^{24} \mathrm{H}$ eydar Shadi, "Interfaith Dialogue and Religious Tolerance in Contemporary Islamic Thought: A Comparative Study of Fethullah Gulen and Abdul Karim Soroush", dalam Peaceful Coexistence: Fethullah Gülen's Initiatives in the Contemporary World, 290.

${ }^{25}$ lbid., 101. 
dalamnya kepentingan-kepentingan budaya dan agama yang beragam.

Dari sinilah muncul ide asimilasi yang disampaikan oleh Ramadhan. Pada satu sisi, Ramadhan merasakan bahwa masalah perbedaan budaya adalah masalah serius yang harus segera diselesaikan. Dan pada sisi lain, ia meyakini bahwa Islam dengan prioritasnya dapat menghadapi masalah itu dengan melakukan asimilasi budaya dengan budaya-budaya lain.

Pada titik ini, ia berbeda dengan Gulen. Gulen tidak pernah mengajukan opsi asimilasi yang berarti peleburan penuh budaya Islam dan budaya Eropa dalam bingkai nilai-nilai universal seperti pluralisme dan demokrasi. Gulen hanya memperjuangkan pluralisme, demokrasi dan yang sejenisnya dalam upaya menyandingkan budaya Islam dengan budaya Eropa. Ia mencoba mengatakan bahwa Islam dan Eropa dapat bersanding. Ramadhan melangkah satu langkah lebih maju dari itu, dan mengingingkan asimilasi dan bukan sekedar kebersandingan. Dengan ungkapan lain, Ramadhan menginginkan Islam yang ter-Eropa-kan yang ia anggap sebagai bentuk dari Islam yang paling modern. ${ }^{26}$

Oleh karena itu, untuk mencapai tujuan Eropanisasi Islam itu, apa yang ingin dilakukan oleh Ramadhan selanjutnya adalah menilik kembali beberapa konsep Islam dan mengkritisinya dalam kontek kehidupan sosial-budaya di Eropa. Pertama-tama ia bahas adalah konsep dapalhæarb dan dapal-Islam. Seperti Gulen, Ramadhan keberatan dengan pemahaman klasik tentang konsep ini yang cenderung menafsirkannya dari sudut pandang teologis dan menghasilkan konklusi diskriminatif. Negara-negara non-Muslim dianggap sebagai dapal-hæarb dan dengan demikian boleh diperangi. Pandangan yang ditawarkan oleh Ramadhan adalah pendekatan geografis; bahwa sebuah negara dapat disebut sebagai daßal-hærb jika memerangi negara kita. Negara itu harus diperangi tidak peduli apakah itu negara Muslim atau tidak. Sementara itu, Eropa tidak dapat dikatakan dapal-hærb karena Eropa "sekarang ini sangat menghormati Islam sebagai agama". ${ }^{27}$

Gulen juga keberatan dengan konsep ini. la tidak menerima keberadaan kedua istilah itu, dan menggantikannya dengan satu istilah yaitu dasal-hizmet (wilayah pengabdian). Artinya, di manapun kita berada, dan di negara manapun kita bekerja, kita haruslah mengabdi pada negara tersebut. Ini adalah bagian dari "tekad untuk melayani Islam dengan memberikan contoh yang baik kepada orang lain, menaati ajaran-ajaran Islam, menghormati hak-hak orang lain, bertindak adil, dan menghindari membicarakan masalah dapal-hæarb dan dapal-Islam." ${ }^{28}$

Dari masalah dapal-hæarb dan dapal-Islam, Ramadhan pindah ke persoalan lain yang ia anggap sebagai unsur penting dalam upaya meng-Eropa-kan Islam, yaitu persoalan personalitas dan identitas Muslim.

Dalam hal personalitas seorang Muslim, Ramadhan menekankan perlunya seorang Muslim memosisikan diri dengan baik dan proporsional dalam tatanan dunia yang sangat plural ini. Dalam pandangannya, personalitas seorang Muslim terdiri dari beberapa hal. Pertama, keimanan dan spiritualitas. Kedua, perbuatan yang merupakan pengejawantahan dari keimanan dan spiritualitas. Ketiga, hak dan kewajiban. Keempat, kebebasan. Kelima, keterlibatan dalam

\footnotetext{
${ }^{26}$ lbid., 150.

$27 \mathrm{lbid}$.

${ }^{28}$ Ibid., 221.
} 
masalah-masalah sosial yang dihadapi oleh masyarakat.

Unsur yang pertama adalah urusan setiap orang Muslim dengan Tuhannya, dan tidak perlu dibawa-bawa dalam ranah publik. Unsur-unsur yang lain, seorang Muslim harus menyesuaikan diri dengan kondisi dan lingkungan tempat ia hidup. Maka dalam hal perbuatan, hak dan kewajiban, kebebasan dan keterlibatan sosial, seorang Muslim seharusnya mengikuti -dan tidak sekedar menghormati- tradisi dan budaya Eropa, jika ia tinggal di Eropa.

Ramadhan meyakini bahwa Eropa terbukti telah memberikan yang terbaik bagi umat Islam yang berada di sana. Eropa telah memberikan kebebasan yang seluas-luasnya kepada ummat Islam untuk beragama, menghormati hak-hak mereka dan melindungi agama mereka. Oleh karena itu, tidak ada alasan bagi orang Muslim untuk tidak menerima "personalitas" Eropa sebagai identitas baru baginya.

Seorang Muslim di Eropa seharusnya juga aktif dalam membangun negara tempat ia tinggal, dan bergaul dengan anggota masyarakat di sana. Seorang Muslim tidak boleh tertutup. Menurut Ramadhan, membuka diri untuk bergaul dengan siapapun adalah implikasi logis dari Shahadah. la menulis:

"Shahadah tidak hanya berarti mengucapkan kesaksian dengan mulut. la juga berarti bahwa seorang Muslim harus bertindak sesuai dengan kaidah yang berlaku dalam masyarakat. Muslim harus beriteraksi. Mengucapkan Shahadah berarti seorang Muslim harus terlibat dalam kegiatan masyarakat secara aktif. la harus turut serta dalam proses menciptakan sistem legal, ekonomi, sosial dan politik yang baik agar terwujud keadilan dan kesetaraan bagi seluruh masyarakat". ${ }^{29}$

Dari dapal-hærb dan daßal-Islam, personalitas dan identitas Muslim, Ramadhan pindah ke persoalan kewarganegaraan. Ini adalah persoalan inti dalam upaya dan misi besar Ramadhan untuk memberikan makna ke-Eropa-an kepada jati diri seorang Muslim. J ika dalam khazanah klasik, hak dan kewajiban seseorang dalam kehidupan bernegara ditentukan oleh status agamanya, maka dalam pandangan Ramadhan hak dan kewajiban itu terkait dengan status kewarganegaraannya. Dalam khazanah klasik, seorang Muslim yang hidup dalam negara Islam akan mendapat hak dan kewajiban yang berbeda dengan seorang non-Muslim. Ramadhan menolak itu. Terlepas dari agama yang kita anut, jika kita hidup dalam negara yang sama sebagai warga negara yang sama, maka kita memiliki hak dan kewajiban yang sama pula.

Pandangan Ramadhan ini bisa juga kita pahami sebagai upaya untuk menggantikan identitas religius seseorang dengan identitas nasionalistik. Dan itu sejalan dengan pandanganpandangan Ramadhan yang sudah dijelaskan di atas mengenai personalitas dan identitas seorang Muslim. Garis besarnya adalah bahwa dalam konteks kebersandingan dan bahkan asimilasi budaya, Islam harus dilebur ke dalam identitas dan personalitas nasional dalam kerangka nilainilai universal seperti pluralisme dan demokrasi.

Mungkin ada yang akan bertanya apakah itu akan mempengaruhi keyakinan seseorang sebagai Muslim? J awaban Ramadhan adalah jelas, bahwa ranah keyakinan adalah urusan seseorang dengan Tuhannya. Dalam kehidupan sosial, seseorang harus melakukan adaptasi

${ }^{29}$ Ibid., 220. 
terhadap kebiasaan, tradisi, dan budaya masyarakat tempat ia hidup.

Dalam ungkapan Gulen, ketika seorang Muslim hidup di sebuah negara asing yang nonMuslim, ia "harus melupakan statusnya sebagai minoritas dan menganggap dirinya sebagai bagian dari mayoritas". ${ }^{30}$ Dengan demikian ia tidak merasa terisolasi dan terasing serta merasa menyatu dengan masyarakat barunya.

Namun harus dipahami dengan baik, bahwa yang ditawarkan oleh Gulen bukanlah asimilasi seperti yang diajukan oleh Ramadhan. Gulen lebih menekankan agar seorang Muslim menunjukkan perilaku yang baik di sebuah masyarakat asing tempat ia hidup dengan menghormati dan bahkan mengikuti tradisi, kebiasaan dan budaya masyarakat itu. Dalam kondisi seperti itu, seorang Muslim tidak harus meleburkan budayanya ke dalam budaya masyarakat yang baru. la dapat mengikuti tradisi barunya tanpa harus mengorbankan budaya aslinya. Bagi Ramadhan strategi yang ditawarkan adalah asimilasi, di mana budaya asli seorang Muslim yang ia bawa dari negara asalnya harus dilebur ke dalam budaya barunya. la harus melepas baju lamanya dan mengenakan baju baru sebagai orang Eropa, kalau ia hidup di Eropa.

Bagi Ramadhan asimilasi adalah mutlak. Jika tidak, maka tidak ada ruang bagi agama (Islam) untuk bisa bertahan di Eropa. la menulis:

"Ruang publik di Eropa telah menjadi sangat non-agamis, dan bahkan anti-agama. Para orang beragama telah mendapatkan bahwa menghadapi situasi semacam ini adalah sangat sulit. Kekuatan maha dahsyat yang dimiliki oleh budaya modern dengan individualisme, uang dan hiburannya telah sedemkian rupa menarik minat banyak orang sehingga sulit bagi agama untuk menghadapinya". ${ }^{31}$

Oleh karena itu, berbagai strategi harus ditawarkan agar agama terutama Islam bisa bertahan dan bahkan berkembang.

Pertanyaan yang sering muncul di kalangan awam di Eropa adalah bahwa pada kenyataannya Islam terus berkembang di sana tanpa harus menerapkan strategi yang ditawarkan oleh Ramadhan. Tidak ada asimiliasi, tidak ada perubahan personalitas dan identitas. Tapi Islam terus bertahan dan bahkan berkembang. Mungkin itu benar. Tapi yang tidak disadari oleh kalangan awam itu adalah bahwa perkembangan Islam itu bukanlah tanpa harga. Islam telah menjadi sumber keresahan banyak orang di Eropa karena keberadaannya -dan sekarang-karena perkembangannya. J ika keresahan itu tidak diredam, maka cepat atau lambat akan meledak dan menjadi bom waktu yang akan menghancurkan umat Islam sendiri. Oleh karena itu, mengEropa-kan orang Islam adalah jalan terbaik, paling tidak dalam pandangan Ramadhan.

Dengan ungkapan lain, Ramadhan mengajak orang Islam di Eropa untuk mengingat apa yang ia sebut sebagai civility logic. Civility logic adalah mengingat status sipil kita. J ika secara sipil kita adalah orang Eropa, maka terlepas dari agama yang kita anut, kita harus mengabdi kepada Eropa. Ini sejalan dengan tawaran Gulen di atas dengan konsepnya dapal-hizmet (wilayah pengabdian).

Demikianlah Gulen dan Ramadhan. Dua tokoh pemikir Muslim masa kini yang telah

\footnotetext{
${ }^{30}$ Fatih Tedik, "Motivating Minority Integration in Western Context: The Gulen Movement in the United Kingdon", dalam Peaceful Coexistence: Fethullah Gülen's Initiatives in the Contemporary World, 229.

${ }^{31}$ bid., 427.
} 
banyak berbuat untuk mengajukan tawaran-tawaran praktis dan diskursif bagi persoalanpersoalan yang dihadapi oleh umat Islam terutama di Eropa. Kajian lebih lanjut tentang keduanya masih diperlukan karena masih banyak sisi-sisi pemikirannya yang belum tersentuh dalam tulisan ini. Semoga tulisan ini dapat menjadi awal bagi kajian-kajian yang lebih serius di masa-masa yang akan datang.

\section{Datar Rujukan}

Alimuhamedov, Farhod, "Peaceful Muslim-non-Muslim Co-existence in Secular Context", dalam Peaceful Coexistence: Fethullah Gülen's Initiatives in the Contemporary World, editor Ihsan Yilmaz et al. Inggris: Leeds Metropolitan University Press, 2007.

Aviv, Efrat E, "The Light of Tolerance Between Rabbi Abraham Kook and Hoja Efendi Fethullah Gulen”, dalam Peaceful Coexistence: Fethullah Gülen's Initiatives in the Contemporary World, editor Ihsan Yilmaz et al, Inggris: Leeds M etropolitan University Press, 2007.

Berger, Peter. Langit Suci: Agama Sebagai Realitas Sosial, terjemahan. J akarta: LP3ES, 1991.

Burke, Peter. Popular Culture in M odern Europe. London: Maurice Temple Smith, 1978. Cutting Edge. Gulen Icon of World Peace, 15-21 Oktober 2008.

Esposito, J ohn L. Dan J ohn O. Voll. Makers of C ontemporary Islam. New York: Oxford U niversity Press, 2001.

Forbes. Gulen Voted no 1 Muslim Leader, 21 J anuari 2008.

Foreign Policy. Gulen World's no 1 Muslim Thinker, Agustus 2008.

Fraser, Nancy. "Rethinking the Public Sphere: A Contribution to the Critique of Actually Existing Democracy" dalam Habermas and the Public Sphere, Craig Calhoun, (ed.). Cambridge: MA: MIT Press, tt.

Geertz, Clifford. Islam O bserved: Religious Development in Morocco and Indonesia. Chicago and London: The University of Chicago Press 1971.

Gidden, Anthony. Central Problem in Social Theory: Action, Structure, and Contradiction in Social Theory. Hongkong: McMillan Education, 1990.

Guardian. Meet World's no I Muslim Leader, Senin 23 J uni 2008.

Gulen, Fethullah. Kunci-kunci Rahasia Sufi, penerjemah Tri Wibowo Budi Susanto. Jakarta:

Srigunting, 2001.

H untington, Samuel. The Clash of Civilisation and the Remaking of World Order. New York: Simon \& Schuster, 1996.

------ .Who Are We? The Chalennges to America's National Identity. New York: Simon \& Schuster, 2004.

- - - - . Political Modernization: America vs Europe, World Politics 18, 3 (1966).

- - - - - . G elombang Demokratisasi Ketiga, terjemahan. J akarta: G rafiti, 1995.

International Herald Tribune. Gulen Voted no 1 M uslim Leader, $18 \mathrm{~J}$ anuari 2008.

Isgandarov, Nazila. "Identity as a Major Factor in Integration to the Western Society", dalam

Peaceful Coexistence: Fethullah Gülen's Initiatives in the Contemporary World, editor Ihsan Yilmaz et al. Inggris: Leeds Metropolitan University Press, 2007. 
J ohnson, Donald. Teori Sosiologi Klasik dan M odern I-II, terjemahan. J akarta: Gramedia, 1988. Kirk, Kate dan G urkan Celik. "Opening the Road to Dialogue: an Amalgamation of Gulen's and Spinoza's Ideas on Tolerance and Dialogue Applied to the Situation of Muslims in the Netherlands", dalam Peaceful Coexistence: Fethullah Gülen's Initiatives in the Contemporary World, editor Ihsan Yilmaz et al. Inggris: Leeds Metropolitan University Press, 2007.

Michel, Thomas. "Fethullah Gulen, Following in the Footsteps of Rumi", dalam Peaceful Coexistence: Fethullah Gulen's Initiatives in the Contemporary World, editor Ihsan Yilmaz et al. Inggris: Leeds Metropolitan University Press, 2007.

Ramadhan, Tariq. To Be a European Muslim. Leicester: The Islamic Foundation, 1999.

Shadi, H eydar. "Interfaith Dialogue and Religious Tolerance in Contemporary Islamic Thought: A Comparative Study of Fethullah Gulen and Abdul Karim Soroush", dalam Peaceful Coexistence: Fethullah Gülen's Initiatives in the Contemporary World, editor Ihsan Yilmaz et al. Inggris: Leeds Metropolitan University Press, 2007.

Siebert, Rudolf. The C ritical Theory of Religion: From Universal Paradigm to Political Theology. Berlin, New York, Amsterdam: Mouton Publishers, 1985.

Turner, Bryan. Sosiologi Islam, Suatu Telaah Analitis atas Tesa Sosiologi Weber, Terjemahan. J akarta: Rajawawli, 1984.

Tedik, Fatih, "Motivating Minority Integration in Western Context: The Gulen Movement in the United Kingdon", dalam Peaceful Coexistence: Fethullah Gülen's Initiatives in the Contemporary World, editor Ihsan Yilmaz et al, Inggris: Leeds Metropolitan University Press, 2007.

Zaman, Muhammad Q asim. The Ulama in Contemporary Islam: Custodians of Change. Princeton: Princeton University Press, 2002.

Voll, J ohn O. "Renewal and Reform in Islamic H istory: Tajdid and Islah", dalam J ohn L. Esposito (ed). Voices of Resurgent Islam, New York: Oxford University Press, 1983.

Yavuz, Sevket dan Davut Ayduz. "Turning from Doom-Laden Soothsayings To Mutual Communication and Wisdom (Ta'aruf)", dalam Peaceful Coexistence: Fethullah G ülen's Initiatives in the Contemporary World, editor Ihsan Yilmaz et al, Inggris: Leeds Metropolitan University Press, 2007. 